UCRL-ID-122450

\title{
Preliminary Report on Isotope Abundance Measurements in Groundwater Samples from the Talbert Injection Barrier Area, Orange County Water District
}

\author{
G. Bryant Hudson \\ M. Lee Davisson \\ Carol A. Velsko \\ Sidney Niemeyer \\ Bradley K. Esser \\ Joan Beiriger \\ Isotope Geochemistry Section \\ Isotope Sciences Division \\ Lawrence Livermore National Laboratory
}

February 1995

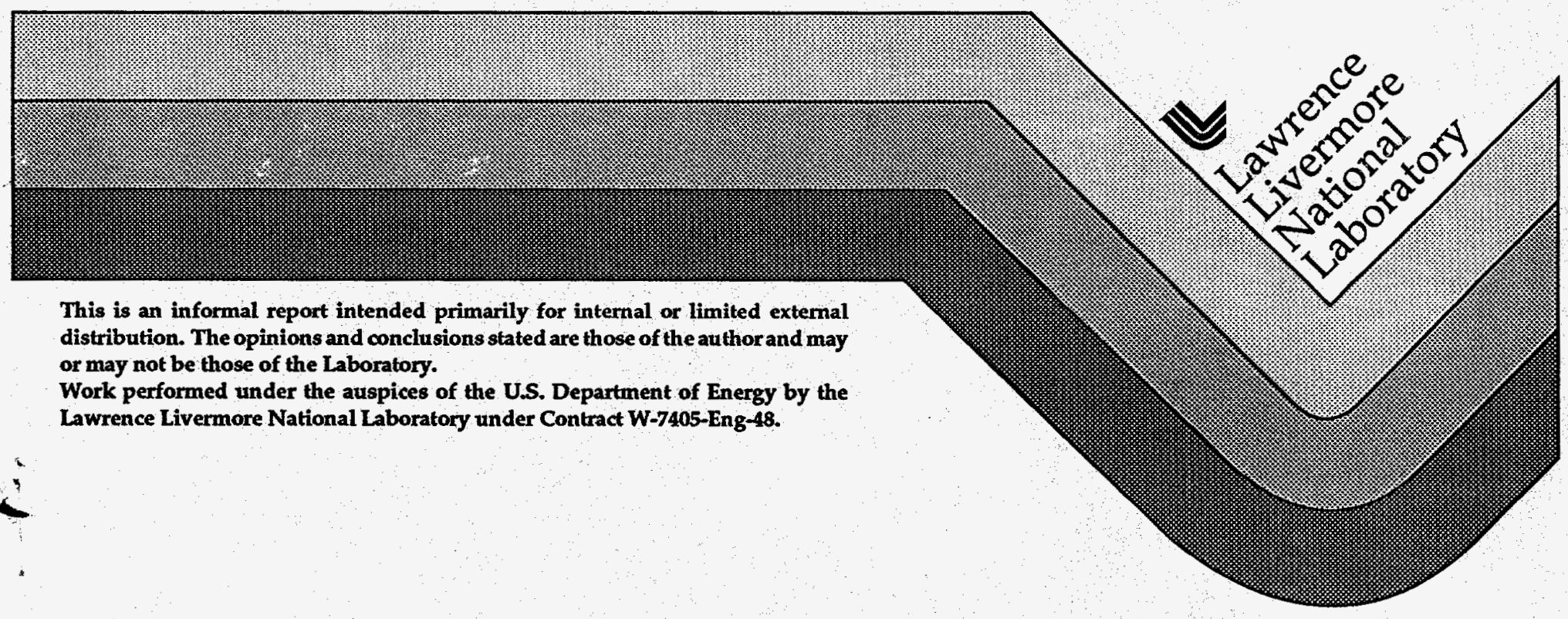




\section{DISCLAIMER}

This document was prepared as an account of work sponsored by an agency of the United States Government. Neither the United States Government nor the University of California nor any of their employees, makes any warranty, express or implied, or assumes any legal liability or responsibility for the accuracy, completeness, or usefulness of any information, apparatus, product, or process disclosed, or represents that its use would not infringe privately owned rights. Reference herein to any specific commercial products, process, or service by trade name, trademark, manufacturer, or otherwise, does not necessarily constitute or imply its endorsement, recommendation, or favoring by the United States Government or the University of California. The views and opinions of authors expressed herein do not necessarily state or reflect those of the United States Government or the University of California, and shall not be used for advertising or product endorsement purposes.

This report has been reproduced directly from the best available copy.

Available to DOE and DOE contractors from the

Office of Scientific and Technical Information

P.O. Box 62, Oak Ridge, TN 37831

Prices available from (615) 576-8401

Available to the public from the National Technical Information Service

U.S. Department of Commerce 5285 Port Royal Rd. Springfield, VA 22161 


\section{DISCLADMER}

Portions of this document may be illegible in electronic image products. Images are produced from the best available original document. 
Preliminary Report on Isotope Abundance Measurements in Groundwater Samples from the Talbert Injection Barrier Area, Orange County Water District

\author{
G. Bryant Hudson \\ M. Lee Davisson \\ Carol Velsko \\ Sidney Niemeyer \\ Brad Esser \\ Joan Beiriger \\ Isotope Sciences Division \\ Lawrence Livermore National Laboratory
}

February 1995 


\section{Introduction}

This report discusses isotope abundance measurements made on a collection of groundwater samples from the Orange County Water District. The water samples were collected in May, 1994 as part of a preliminary study conducted by LLNL to assess the feasibility of tracing and dating reclaimed water used in the Talbert Injection Barrier. A set of samples were collected both near to and far from the barrier and also at different depths in available monitoring wells. A variety of elements were selected for isotopic analysis; hydrogen (tritium), helium, neon, carbon, chlorine and strontium and the results are given in Table 1 . The tritium abundance combined with the ${ }^{3} \mathrm{He}$ and $\mathrm{Ne}$ abundance provides a method for age dating young ( $<40 \mathrm{yr}$.) groundwater. The abundance of ${ }^{14} \mathrm{C}$ provides an age dating technique for older (1000-50,000 yr.) groundwater. The concentrations of $\mathrm{Cl}$ and $\mathrm{Sr}$ isotopes give information on sea water mixing and water-rock chemical interactions.

\section{General Aqueous Chemistry}

Groundwater in and around the Talbert Gap and barrier region range in total dissolved solids (TDS) from $\sim 300 \mathrm{mg} / \mathrm{L}$ to as high as $15,500 \mathrm{mg} / \mathrm{L}$. The lowest TDS water occurs in close proximity to the groundwater barrier while the highest TDS groundwater occurs adjacent to the ocean shore (M-31). Figure 1 is a Piper diagram of the different groundwaters sampled during this study. Figure 2 is a map showing well location. In fig. 1 , in the cation triangle, groundwater occurs as a mixture between a predominantly Ca-rich end member and a predominantly Na-rich end member with most samples lying in between the two types. In the anion triangle the data ranges from a $\mathrm{HCO} 3$-rich end member to a $\mathrm{Cl}$-rich end member but with a mixture of the two with a water that has a higher proportion of $\mathrm{SO}_{4}$. In the combined field of the data above the ionic triangles, four distinct end member groundwaters are discernible, 1) a CaHCO3-type groundwater with moderately low TDS $(\sim 100-800 \mathrm{mg} / \mathrm{L}), 2)$ a $\mathrm{NaHCO}_{3}$ groundwater with a low TDS $(\sim 300 \mathrm{mg} / \mathrm{L}), 3)$ a $\mathrm{NaCaHCO}_{3}$ groundwater that has some of the lowest TDS values $(-200 \mathrm{mg} / \mathrm{L})$ but also range up to $\sim 600 \mathrm{mg} / \mathrm{L}, 4)$ a NaCl water with the highest TDS values.

As will be further indicated by the isotope data, the $\mathrm{CaHCO}_{3}$ groundwater is related to natural shallow groundwater that has been unaffected by injection water. $\mathrm{The}^{\mathrm{NaHCO}} 3$ water is from the deeper aquifers. Its high $\mathrm{Na}$ relative to $\mathrm{Ca}$ is probably due to ion exchange processes on clay sites, a process that takes 100's to 1000's of years and is consistent with the older ages of the deep groundwaters (see below). Nevertheless, the 
$\mathrm{Na} / \mathrm{Ca}$ ratio contrast between the deep groundwater and the shallow natural groundwater is obvious.

Water used for injection is treated waste water blended with the deeper groundwater (DW-1). The mixed water (Q-10) has a $\mathrm{NaCaHCO}_{3}$ character and lies just outside the larger field of $\mathrm{NaCaHCO}_{3}$ (Fig 1) groundwaters sampled from monitoring wells surrounding the barrier. A general mixing of the $\mathrm{CaHCO}_{3}$ groundwater and the $\mathrm{NaCaHCO}_{3}$ injected water (Q-10) is apparent where the field of barrier water forms a cluster intermediate to either end member. The high TDS $\mathrm{NaCl}$ groundwater is undoubtedly the sea water intrusion where the $\mathrm{NaCl}$ water mixes with a $\mathrm{CaHCO}_{3}$ groundwater.

\section{Tritium - Helium-3 dating of OCWD Groundwaters}

Age dating of the injected water measures the time between sampling and the last time the water was in equilibrium with the atmosphere shortly before being injected into the ground. For the short ages expected (less than 20 years), the tritium $\left({ }^{3} \mathrm{H}\right)$ - helium-3 $\left({ }^{3} \mathrm{He}\right)$ system provides an excellent dating technique. Tritium is a naturally occurring radioactive isotope of hydrogen (half-life $=12.4 \mathrm{yr}$.) and is produced by cosmic-ray interactions in the atmosphere. Tritium decays by emitting a low energy electron (average energy about 20 $\mathrm{keV}$ ). In doing so, it becomes a stable ${ }^{3} \mathrm{He}$ atom. In addition to cosmic ray production, ${ }^{3} \mathrm{H}$ is released into the environment by human activities such as nuclear energy production and biomedical research. The ${ }^{3} \mathrm{H}-3 \mathrm{He}$ dating technique relies on being able to identify ${ }^{3} \mathrm{He}$ in water samples due to the decay of ${ }^{3} \mathrm{H}$. When a ${ }^{3} \mathrm{H}$ atom, as part of a water molecule, decays in a saturated aquifer, the resulting ${ }^{3} \mathrm{He}$ atom remains in solution and continues to move with the water. Thus the sum of ${ }^{3} \mathrm{H}$ and ${ }^{3} \mathrm{He}$ atoms per unit volume remains constant and equals the number of ${ }^{3} \mathrm{H}$ atoms initially present. Knowing the original number of ${ }^{3} \mathrm{H}$ atoms and the current number of ${ }^{3} \mathrm{H}$ atoms, we compute the age by:

$$
\text { (number }{ }^{3} \mathrm{H} \text { now) } /\left(\text { number }{ }^{3} \mathrm{H} \text { originally) }={ }^{3} \mathrm{H} /\left({ }^{3} \mathrm{H}+{ }^{3} \mathrm{He}\right)=\mathrm{e}^{-0.0558 \mathrm{~T}}\right.
$$

where ${ }^{3} \mathrm{H}$ is the number of ${ }^{3} \mathrm{H}$ atoms, ${ }^{3} \mathrm{He}$ is the number of ${ }^{3} \mathrm{He}$ atoms due to ${ }^{3} \mathrm{H}$ decay, (the decay constant $=\ln (2) / t_{1} / 2=0.0558$ ) and $\mathbf{T}$ is the age in years. In general, this technique works because ${ }^{3} \mathrm{He}$ is naturally very rare. The abundance of ${ }^{3} \mathrm{He}$ in groundwater (without ${ }^{3} \mathrm{H}$ present) of about 1 part in $10^{13}$. This technique has been applied successfully in several circumstances. Recent work of Ekwurzel et al.(1994) has compared ${ }^{3} \mathrm{H}-{ }^{3} \mathrm{He}$ dating to two other dating techniques ( $85 \mathrm{Kr}$ and chlorofluorocarbons) and has shown excellent agreement exists for all three dating systems. 
In groundwater, $\mathrm{He}$ and $\mathrm{Ne}$ come from interaction with the atmosphere before and during recharge and from the build up of nuclear reaction products such as ${ }^{3} \mathrm{He}$ from ${ }^{3} \mathrm{H}$ decay after recharge. In some simple systems, ${ }^{4} \mathrm{He}$ comes only from the atmosphere and can be used to directly monitor how much ${ }^{3} \mathrm{He}$ comes from the atmosphere. However when older ( $>$ about 5,000 yr.) groundwater is present, we find contributions from the decay of $\mathrm{U}$ and $\mathrm{Th}$ which produce ${ }^{4} \mathrm{He}$ (alpha particles) and we can no longer use ${ }^{4} \mathrm{He}$ as an air monitor. The decay of $\mathrm{U}$ and $\mathrm{Th}$ also indirectly produce a small amount of ${ }^{3} \mathrm{He}$ but it is negligible for the OCWD samples considered here.

For the OCWD samples, we have chosen to use the abundance neon to determine how much ${ }^{3} \mathrm{He}$ comes from sources other than ${ }^{3} \mathrm{H}$ (These equations are an approximation that is appropriate for samples with little excess air).

$$
\begin{array}{lll}
{ }^{3} \mathrm{He} \text { (meas) } & = & { }^{3} \mathrm{He}(\text { air })+{ }^{3} \mathrm{He}(\text { tritium }) \\
{ }^{20} \mathrm{Ne} \text { (meas) } & = & 20 \mathrm{Ne}_{(\text {air })}
\end{array}
$$

$$
\text { or: } \quad{ }^{3} \mathrm{He}(\text { tritium })=20 \mathrm{Ne}(\text { meas }) *\left(\left({ }^{3} \mathrm{He} / 22 \mathrm{Ne}\right)(\text { meas })-\left({ }^{3} \mathrm{He} /{ }^{22} \mathrm{Ne}\right)(\text { air })\right)
$$

Figure 3 illustrates that the ratio of $3 \mathrm{He} / 22 \mathrm{Ne}$ is constant in samples where we know there is not ${ }^{3} \mathrm{He}$ from ${ }^{3} \mathrm{H}$ decay. In contrast, samples containing injection water show elevated levels of ${ }^{3} \mathrm{He}$ from ${ }^{3} \mathrm{H}$ decay. Table 2 gives ${ }^{3} \mathrm{H}-{ }^{3} \mathrm{He}$ ages for samples containing measurable ${ }^{3} \mathrm{H}$. Samples not showing detectable ${ }^{3} \mathrm{H}$ correspond to ages greater than 40 years.

Measured ${ }^{3} \mathrm{H}$ concentrations in OCWD samples range from essentially zero $\left(<3 \times 10^{4}{ }^{3} \mathrm{H}\right.$ atoms/gram) to rather high levels (about $5 \times 10^{7}{ }^{3} \mathrm{H}$ atoms/gram, drinking water standard $=4 \times 10^{8}{ }^{3} \mathrm{H}$ atoms/gram). Tritium concentrations are often reported using a variety of units:

$$
\begin{aligned}
1 \text { Tritium unit (TU) } & =6.7 \times 10^{4}{ }^{3} \mathrm{H} \text { atoms/gram } \\
1 \mathrm{pCi} / \text { liter } & =0.3 \mathrm{TU} \\
& =\quad 2.0 \times 10^{4}{ }^{3} \mathrm{H} \text { atoms/gram. }
\end{aligned}
$$

The low ${ }^{3} \mathrm{H}$ concentrations are associated with wells not containing reclaimed water (far away from the injection barrier) and are interpreted to represent groundwater residence ages greater than 40 years. The ${ }^{3} \mathrm{H}$ concentrations in some of the samples are higher than found in typical surface waters and must have some local origin. The high levels of ${ }^{3} \mathrm{H}$ observed 
in the injection water are also accompanied with elevated levels of ${ }^{14} \mathrm{C}$ and the atom ratio of ${ }^{3} \mathrm{H} /{ }^{14} \mathrm{C}$ ranges from about 1 to 3 , which is strongly suggestive of biomedical research waste streams. The ${ }^{3} \mathrm{H}$ and ${ }^{14} \mathrm{C}$ are present at concentrations well below current drinking water standards for all samples examined in this work.

The majority of the measured ${ }^{3} \mathrm{H}-{ }^{3} \mathrm{He}$ ages are short compared to the half-life of ${ }^{3} \mathrm{H}\left(12.4\right.$ years) and we see much more ${ }^{3} \mathrm{H}$ than ${ }^{3} \mathrm{He}$ in the samples. Roughly the ${ }^{3} \mathrm{H}-{ }^{3} \mathrm{He}$ ages increase with distance from the injection barrier. The M-21 well is quite close to the barrier and shows very little ${ }^{3} \mathrm{He}$ from ${ }^{3} \mathrm{H}$ decay despite high ${ }^{3} \mathrm{H}$ levels. The $\mathrm{M}-21$ well samples water at four depths and is located about $400 \mathrm{ft}$. down gradient from the injection barrier. The ages of the four levels range from 0.5 to 1.7 years. The uncertainties in the ages due to analytical measurement uncertainties are fairly small and suggest that there are resolvable differences, however there are additional uncertainties due to the effects of dispersion. These effects are hard to quantify at this point, but are of some concern since the ${ }^{3} \mathrm{H}$ content of the injected water apparently fluctuates significantly leading to significant ${ }^{3} \mathrm{H}$ concentration gradients. Based on the modeling work of Soloman and Sudicky (1991) it appears that errors due to dispersive transport of ${ }^{3} \mathrm{He}$ will be much less than a factor of two.

Monitoring well M-19 is at a similar distance up-gradient from the injection barrier. The upper section of M-19 (M-19-1) shows only a trace of ${ }^{3} \mathrm{H}$ indicating that injection water is largely not present. But in the lower sections, we see ages comparable to those for M-21. Based on wells M-19 and M-21 we conclude that the average groundwater speed is about $400 \mathrm{ft}$. per year. The monitoring wells $\mathrm{M}-7 \mathrm{a}$ (down gradient) and M-11 (up-gradient) are similar to M-21 and M-19 but are roughly a bit more than twice as far away from the barrier. Their ages range from 2.1 to 3.4 years, which again corresponds to a groundwater speed away from the barrier of about $400 \mathrm{ft}$ per year. The HB-Dyke well is about the same distance as $\mathrm{M}-7 \mathrm{a}$ and $\mathrm{M}-11$ but is at the edge of the injection barrier and it shows a ${ }^{3} \mathrm{H}-{ }^{3} \mathrm{He}$ age of 2.5 years indicating a groundwater travel speed just slightly larger than the other wells.

The next closest well to the barrier that we sampled (Saki-FV) shows little or no ${ }^{3} \mathrm{H}$ present. The Saki-FV well is about $5000^{\prime}$ up-gradient of the injection barrier. If we assume 18 years of water injection and $400 \mathrm{ft} / \mathrm{yr}$. speed, injection water would have reached the Saki-FV well in about 12 years, which is apparently not the case. Of course at a distance this large, the injection barrier begins to looks more like a point source than a line source and the flow speed would be slower at larger distances. The M-26 well is about 7000' down-gradient from the injection barrier and shows no ${ }^{3} \mathrm{H}$. This sample received extra 
attention in the ${ }^{3} \mathrm{H}$ measurement and shows less than $0.1 \mathrm{TU}$ of ${ }^{3} \mathrm{H}$. Based on this limit we can be confident that injection water constitutes less than $1 \%$ of the M-26 water.

\section{Water Mixing Ratios}

In order to understand the meaning of these ${ }^{3} \mathrm{H}-{ }^{3} \mathrm{He}$ ages, we need to evaluate the mixing ratio of injection water with ambient background water (i.e. the water present in the aquifer before the injected water arrived). Several samples were collected at sufficient distance to completely preclude the possibility of injection water being present, in particular the CTG-1 well (4 different zones). All of the samples away from the barrier show little if any ${ }^{3} \mathrm{H}$. In addition, we see ${ }^{14} \mathrm{C}$ well below modern levels for these ambient water samples. The lack of ${ }^{3} \mathrm{H}$ and low values for ${ }^{14} \mathrm{C}$ (and ${ }^{36} \mathrm{Cl}$ ) indicate that the ambient water away from the barrier is at least 40 years old and probably 100's to 1000's of years old. Because the ambient water contains no ${ }^{3} \mathrm{H}$, the ${ }^{3} \mathrm{H}-{ }^{3} \mathrm{He}$ ages reported in Table 2 are just the age of the injected water. The ${ }^{3} \mathrm{H}-{ }^{3} \mathrm{He}$ age is the mean age of the ${ }^{3} \mathrm{H}$ in the system. Therefore, the addition of ${ }^{3} \mathrm{H}$-free water has no effect on the apparent age.

In addition to measuring the age, we estimated the relative contributions between injection water and ambient water. The clearest indication of the presence of injection water is the observation of ${ }^{3} \mathrm{H}$. However, because the ${ }^{3} \mathrm{H}$ concentration in the injection water is variable, ${ }^{3} \mathrm{H}$ information is only useful in determining if any injection water is present. For example, the sample M19-1 shows a little less than $1 \%$ of the average injection water ${ }^{3} \mathrm{H}$ concentration. As a result, we can conclude that virtually no injection water has reach this point. All of the isotope abundance data and physical measurements (i.e. temperature) show some distinction between ambient and injected water, but most of the injection water isotopes have been variable over the course of time and this complicates their interpretation. One element, neon, appears to be fairly constant in the injection water. Most groundwater contains neon at concentrations about 30-40\% greater than the prediction of equilibrium solubility with the atmosphere. This effect is generally attributed to the incorporation of air in the vadose zone at the transition from unsaturated to saturated conditions. The actual nature of this 'excess air' component is uncertain, but it is present in virtually all naturally occurring groundwater. We were surprised initially when many of the samples showed little or no excess air, however it seems clear that the injection water is in equilibrium with the atmosphere and never goes through the recharge process that incorporates 'excess air' in groundwater. While the neon concentration of the injection water appears to be constant, the amount of 'excess air' in the ambient water is likely to be somewhat variable, so in contrast to using ${ }^{3} \mathrm{H}$, this indicator is only useful when the fraction of injection water is 
near one. Using ${ }^{3} \mathrm{H}$ and neon we can sort the samples into three categories, either 1) samples containing little or no injection water, 2) samples consisting mostly of injection water, and 3) sample containing significant amounts of both injection water and ambient water. Table 3 shows these groupings and gives group averages for some of the measured parameters.

\section{Carbon in OCWD Groundwaters}

Natural Shallow Groundwater - The carbon isotope signatures of shallow groundwater that have no apparent mixed injected water can best be seen in wells WM-3, SAKI-FV, CTG1-1 and 2, and M19-1. The $\delta^{13} \mathrm{C}$ ( $\delta 13 \mathrm{C}$ is defined as the deviation of ${ }^{13} \mathrm{C} /{ }^{12} \mathrm{C}$ from a standard ratio in parts per thousand) values of these groundwaters range from -10.9 to $-13.5 \%$, and they are of the $\mathrm{CaHCO}_{3}$-type groundwater with alkalinity around $200 \mathrm{mg} / \mathrm{L}$. The range in concentration and $\delta^{13} \mathrm{C}$ values are typical for natural groundwaters recharging young alluvial basins in California. Such groundwaters recharge through predominantly $\mathrm{C}_{3}$ type plant roots and probably establish their ${ }^{13} \mathrm{C}$ signatures under semi-open to open conditions. The $\delta^{13} \mathrm{C}$ values of the groundwaters are 12 to $15 \%$ higher than the expected average $\delta^{13} \mathrm{C}$ value of plant respired $\mathrm{CO}_{2}$ of $-25 \%$. Under equilibrium fractionation between dissolved $\mathrm{HCO}_{3}$ and $\mathrm{CO}_{2}$ gas, the difference should be around 9 to $10 \% \circ$ at $\sim 20^{\circ} \mathrm{C}$ mean temperature. The small discrepancy between the expected and observed fractionation could be accounted for in 1) groundwater recharge under semiopen conditions in the vadose zone particularly during $\mathrm{pH}$ neutralization through any calcite dissolution, which would drive the $\delta^{13} \mathrm{C}$ value of the $\mathrm{HCO}_{3}$ slightly higher, or 2) a mixture of $\mathrm{C}_{4}$ plants (perhaps grasses) occur in the recharge area and is contributing a higher $\delta^{13} \mathrm{C}$ component to the root zone $\mathrm{CO}_{2}$. Mixing of atmospheric $\mathrm{CO}_{2}$ has not been explored and further field work and modeling is needed to characterize this difference.

The ${ }^{14} \mathrm{C}$ abundances in these shallow groundwaters range from 58 to $83 \mathrm{pmc}$. Wells WM-3 and Saki-FV share common aquifers and have almost identical ${ }^{14} \mathrm{C}$ abundances. On the other hand, CTG1-1 and M19-1 also share similar aquifers, but have differing ${ }^{14} \mathrm{C}$ abundances. Well M19-1 and possibly well Saki-FV have measurable ${ }^{3} \mathrm{H}$ suggesting that the water discharging from these two wells are a mixture of young and old water. M19-1 may also have a small mixture of injection water that contributes the minor ${ }^{3} \mathrm{H}$ levels. Further work is needed to understand the extent of mixing in the aquifers and well discharges.

The calculated ages for the groundwater in these wells range from $\sim 1500$ (Saki-FV) to 4500 (CTG1-2) years old. These are maximum possible ages for these groundwaters. 
It is possible that when these groundwaters recharged their ${ }^{14} \mathrm{C}$ abundances were slightly modified by calcite dissolution under semi-open conditions. For example, if the discrepancy noted in the $\delta^{13} \mathrm{C}$ values was due entirely from semi-open conditions during recharge, then a potential $20-30 \%$ of the $\mathrm{HCO}_{3}$ dissolved in the groundwater could be from dead carbon that did not re-equilibrate with the soil $\mathrm{CO}_{2}$, and hence, reduced the total ${ }^{14} \mathrm{C}$ abundance of the recharge water by 20-30 pmc. Under these circumstances, wells WM-3, SAKI-FV, and M19-1 may be younger than 100 years but older than 40 years. Groundwaters younger than 40 years typically have bomb-pulse ${ }^{14} \mathrm{C}$ abundances that resulted from injection of excess ${ }^{14} \mathrm{C}$ into the upper atmosphere during atmospheric testing in the 1950's and 1960's. CTG1-1 and 2, on the other hand, would still be less than 100 pmc with a $20-30$ pmc correction of ${ }^{14} \mathrm{C}$ data. Therefore, the youngest possible ages are $\sim 400$ years for CTG1-1 and $\sim 1100$ years for CTG1-2.

Deep Groundwater - Two well waters sampled and analyzed define the deep groundwater in this area. These are DW-1 completed to (?) and CTG1-4 perforated from 1060 to 1220 feet below the surface. Both wells show ${ }^{14} \mathrm{C}$ abundances of $\sim 28 \mathrm{pmc}$. Their $\delta^{13} \mathrm{C}$ values though differ by $3.3 \%$, with the lower value in CTG1-4. The calculated apparent ${ }^{14} \mathrm{C}$ age for both wells is 10,500 years old. The $\delta^{13} \mathrm{C}$ values of both these wells are lower than the $\delta^{13} \mathrm{C}$ values observed in the shallow groundwaters. Two possible reasons explain this difference, 1) the deeper groundwater recharged under different root zone conditions than the shallow groundwaters, such that in the absence of calcite dissolution, the soil $\mathrm{CO}_{2}$ dissolved in the infiltrating waters but did not fully equilibrate with the soil $\mathrm{CO}_{2}$ gas, a condition that might exist under rapid recharge, 2) organic carbon of the deeper aquifer is oxidizing to $\mathrm{CO}_{2}$ that adds a low $\delta^{13} \mathrm{C}$ value $\mathrm{HCO}_{3}$ to the groundwater. The deeper aquifer is high in fine organic particulate matter that should have typical low $\mathrm{d}^{13} \mathrm{C}$ values. It is possible that the ${ }^{13} \mathrm{C}$ in the organic matter is simply exchanging with the dissolved $\mathrm{HCO}_{3}$, but such exchanges would expected to be very slow. The oxidation of organic matter seems more plausible at this time. Furthermore, the deep groundwater is of a NaHCO3-type that probably reached a high $\mathrm{Na} / \mathrm{Ca}$ ratio by ion exchange on clay sites. Such ion exchange would cause calcite to be undersaturated in the groundwater and promote dissolution of carbon-bearing phases.

Let us assume that the original groundwater had a $\delta^{13} \mathrm{C}$ value of $\sim-12.0 \%$ o before any oxidized organic $\mathrm{CO}_{2}$ is added to the groundwater, the $\delta^{13} \mathrm{C}$ value of the organic matter is $-27.0 \%$, and the organic matter is ${ }^{14} \mathrm{C}$ depleted. By mass balance calculation, this would suggest that $22 \%$ of the $\mathrm{HCO}_{3}$ in well DW-1 is derived from dead organic 
matter, and $44 \%$ is from dead organic matter in well CTG1-4. Applying these percentages to the ${ }^{14} \mathrm{C}$ abundances, then the resulting ${ }^{14} \mathrm{C}$ for $\mathrm{DW}-1$ would be $35 \mathrm{pmc}$ and for CTG14,50 pmc. These give comparative calculated ages of $\sim 8700$ years for DW-1 and $\sim 5700$ years to CTG1-4. These ages probably represent a minimum age for these groundwaters. Further work is needed to test the source of the dissolved carbon in the deep groundwater and the extent of any carbon exchange.

Talbert Gap Groundwater - Three non-injected waters were measured in the Talbert Gap south of the barrier where sea water intrusion historically has been a problem. These wells include SA10-1, M-31, and sea water collected at the Newport Pier. The chlorine concentration of the water increases from $2100 \mathrm{mg} / \mathrm{L}$ in SA10-1 to $19,500 \mathrm{mg} / \mathrm{L}$ in the sea water, with M-31 being about half the salinity of the ocean. The alkalinity of the groundwater increases from $300 \mathrm{mg} / \mathrm{L}$ at SA10-1 to $600 \mathrm{mg} / \mathrm{L}$ at $\mathrm{M}-31$. The $\delta^{13} \mathrm{C}$ value of the sea water sample is $+1.5 \%$, a value expected for sea water $\mathrm{HCO}_{3}$ in equilibrium with atmospheric $\mathrm{CO}_{2}$. The ${ }^{14} \mathrm{C}$ abundance of the sea water is $106 \mathrm{pmc}$, indicating incorporation of bomb-pulse atmospheric ${ }^{14} \mathrm{C}$. The current level of atmospheric ${ }^{14} \mathrm{C}$ in $\mathrm{CO}_{2}$ is $\sim 114 \mathrm{pmc}$. The sea water has less ${ }^{14} \mathrm{C}$ than the atmosphere most likely due to up welling of deep bottom waters off the Pacific Coast that are hundreds of years old and have lower ${ }^{14} \mathrm{C}$ abundances.

Well SA10-1 has a $\delta^{13} \mathrm{C}$ value similar to the shallow groundwaters discussed above. The ${ }^{14} \mathrm{C}$ abundance of this well water, though, is only 25 pmc. Likewise, $\mathrm{M}-31$ has a $\delta^{13} \mathrm{C}$ value of $-2.1 \%$ and a ${ }^{14} \mathrm{C}$ abundance of only $5 \mathrm{pmc}$. The chlorine concentration indicates sea water intrusion and mixing with the potable groundwater in the Talbert Gap, but the carbon isotopes are behaving independently of simple conservative mixing and appear to be controlled by water-rock reactions. This is evidenced in the fact that the alkalinity increases toward the ocean simultaneous with the isotopic shifts. The fact that the ${ }^{14} \mathrm{C}$ abundance is decreasing towards the ocean and the $\delta^{13} \mathrm{C}$ value is increasing suggests that a "dead", inorganic carbon source is dissolving into solution as the salinity of the water increases. This carbonate source is most likely sea shells deposited within the near shore fluvial-marine sediments of the gap. Sea shells will have $\mathrm{d}^{13} \mathrm{C}$ values around $0 \%$ and probably "dead" $14 \mathrm{C}$. As a result, the dissolution of the seashells into the groundwater causes a rise in the $\delta^{13} \mathrm{C}$ of the dissolved $\mathrm{HCO}_{3}$ in the groundwater and a decrease in the ${ }^{14} \mathrm{C}$ abundance. A mass balance calculation between mixing of sea water alkalinity with the original freshwater alkalinity suggests that the freshwater that mixed in M-31 should have an alkalinity of $\sim 30 \mathrm{mg} / \mathrm{L}$. Likewise the same mass balance calculation 
for SA10-1 suggests that the original freshwater alkalinity should be $\sim 70 \mathrm{mg} / \mathrm{L}$. These values are low compared to the natural shallow waters further north and more work is needed to resolve this discrepancy. Moreover, simple calcite solubility calculations indicate that dissolution of calcite should not be occurring at the observed rate and further study is needed.

Injection Water - The ${ }^{14} \mathrm{C}$ values of groundwater that are considered in this report to be derived from injected waste water vary from 80 to $550 \mathrm{pmc}$. Most of the waste water values exceed that which is expected for bomb-pulse carbon signatures, and indicate another anthropogenic source. The high ${ }^{14} \mathrm{C}$ values are closely associated with high ${ }^{3} \mathrm{H}$ levels and suggest sources from biomedical tracer research, which could easily be incorporated in the Orange County waste stream. The levels of ${ }^{14} \mathrm{C}$ and ${ }^{3} \mathrm{H}$ in this report fall safely below the current drinking water standards for these radio-elements.

The ${ }^{14} \mathrm{C}$ values for Waste water $22 \mathrm{~A}$ and $22 \mathrm{~B}$, both collected $5 / 94$, are below 100 pmc. This suggests that the high ${ }^{14} \mathrm{C}$ values observed in barrier wells are a result of a transient ${ }^{14} \mathrm{C}$ pulse(s) that has entered the waste-water stream. Comparison of the ${ }^{14} \mathrm{C}$ values and the ${ }^{3} \mathrm{H}-{ }^{3} \mathrm{He}$ ages calculated in this report, indicate that the highest ${ }^{14} \mathrm{C}$ values in the waste water occurred approximately 2 years ago. The ${ }^{14} \mathrm{C}$ values decreased to more environmental levels in the waste water subsequent to this time. Carbonate scale from a re carbonation pond manifold was sampled at the water factory during this study. The scale builds up over a period of about a year (T. Sovitch, pers. comm.). The scale also has an elevated ${ }^{14} \mathrm{C}$ value. The presence of high ${ }^{14} \mathrm{C}$ in the carbonate suggests that the ${ }^{14} \mathrm{C}$ pulse in the waste water stream has been recirculated by incorporation into flocculated lime and reintroduced into the waste water via the $\mathrm{CO}_{2}$ off-gas from the regeneration plant. This recirculation in effect creates a longer residence time for ${ }^{14} \mathrm{C}$ in the water factory treatment process.

The $\delta^{13} \mathrm{C}$ values for the waste water are distinguishable from the natural groundwater. Waste water $22 \mathrm{~A}$ has the lowest value of $-30.4 \%$. The ${ }^{13} \mathrm{C}$ is slightly enriched to $-24.3 \%$ o during the RO process. The low $\delta^{13} \mathrm{C}$ values are probably mostly controlled by the $\delta^{13} \mathrm{C}$ value of the $\mathrm{CO}_{2}$ in the recarbonation pond, which is most likely less than $-35.0 \%$. The $\delta^{13} \mathrm{C}$ of the scale carbonate $(-29.5 \%$ ) also provides evidence for the low value for the $\mathrm{CO}_{2}$.

\section{Chlorine and Strontium in OCWD Groundwaters}

Stable chlorine is an excellent tracer for sea water intrusion into the groundwater system. Elevated $\mathrm{Cl}$ levels are seen in samples from $\mathrm{M}-31, \mathrm{M}-28, \mathrm{SA}-10$ and $\mathrm{M}-26$. In 
addition to the stable $\mathrm{Cl}$ isotopes, we measured Chlorine- $36\left({ }^{36} \mathrm{Cl}\right)$, a radioactive isotope, with half-life of about 300,000 years. Chlorine- 36 is produced mainly by cosmic-ray interactions with argon in the atmosphere. Since ${ }^{36} \mathrm{Cl}$ has a different origin than stable $\mathrm{Cl}$, we might expect to see variable mixing of $\mathrm{Cl}$ sources in the OCWD samples. Figure 4 shows a graph of ${ }^{36} \mathrm{Cl} / \mathrm{Cl}$ vs. $1 / \mathrm{Cl}$ for the OCWD groundwater samples. Sea water is high in $\mathrm{Cl}$ but very low in ${ }^{36} \mathrm{Cl}$, precipitation is low in $\mathrm{Cl}$ but relatively high in ${ }^{36} \mathrm{Cl}$. In fig. 4 , mixing between sea water and a poorly defined meteoric source is observed. Evaporation can produce horizontal movement of points in this type of graph and probably explains the broad horizontal distribution of data seen in fig. 4 .. In general, the ${ }^{36} \mathrm{Cl}$ is completely consistent with sea water being the source of $\mathrm{Cl}$ in the $\mathrm{Cl}$-rich samples, but is not especially definitive. Probably more interesting is the lack of elevated ${ }^{36} \mathrm{Cl}$ concentrations in samples with high ${ }^{3} \mathrm{H}$ and ${ }^{14} \mathrm{C}$. The lack of ${ }^{36} \mathrm{Cl}$ rules out nuclear energy production as a source of the high ${ }^{3} \mathrm{H}$ and ${ }^{14} \mathrm{C}$. Since $\mathrm{Cl}$ is a common element and ${ }^{35} \mathrm{Cl}$ has a large probability for capturing neutrons thus making ${ }^{36} \mathrm{Cl}$, any nuclear power production or research produces lots of ${ }^{36} \mathrm{Cl}$ along with other isotopes such as ${ }^{3} \mathrm{H}$ and ${ }^{14} \mathrm{C}$.

The isotope ratio of ${ }^{87} \mathrm{Sr} /{ }^{86} \mathrm{Sr}$ is often of interest in groundwater investigations as a tool for investigating water-rock chemical interaction. Here we focus just on the elemental concentration of Sr. Strontium is present at low concentration in the injected water. The $\mathrm{Sr}$ concentration in shallow groundwaters away from the injection barrier are much higher (500ppb vs. $35 \mathrm{ppb}$ ) so it is interesting to look at the evolution of the $\mathrm{Sr}$ concentration in the injection water. Figure 5 shows a graph of $\mathrm{Sr}$ concentration vs. the ${ }^{3} \mathrm{H}-{ }^{3} \mathrm{He}$ age. There is a rough increasing trend in $\mathrm{Sr}$ concentration with age. The rate of increase in the $\mathrm{Sr}$ concentration is quite rapid relative to dissolution of aquifer materials and is probably more likely due to ion-exchange effects of weathered materials. Whatever the precise reason, here we see another parameter correlating with age in a expected fashion.

\section{Summary}

The injection water is easily traced by measuring ${ }^{3} \mathrm{H}$. By adding measurements of helium and neon, we can accurately determine how long the injected water has been underground using the ${ }^{3} \mathrm{H}-{ }^{3} \mathrm{He}$ dating technique. The measured ages of the injected water combined with estimated travel distances give an average flow velocity of about $400 \mathrm{ft}$ per year near the injection barrier. The mixing ratio between injected water and ambient water can be roughly estimated from ${ }^{3} \mathrm{H}$ and neon abundance data. In the majority of cases, the sampled water is either mostly injection water or mostly ambient water. Measurement of carbon isotopes suggests that ambient groundwater is fairly old, perhaps some as old as 10,000 years. 


\section{Future work on the injection barrier system}

In this work, application of the ${ }^{3} \mathrm{H}-{ }^{3} \mathrm{He}$ method to dating injected water is straightforward. We recommend that these measurements be repeated for confirmation and to begin to look for temporal variations. Questions about the role of ${ }^{3} \mathrm{He}$ diffusion could be better answered with additional ${ }^{3} \mathrm{H}-{ }^{3} \mathrm{He}$ measurements. In general if we get the same age at different samplings, then diffusion of He is not a concern.

Based on measured ${ }^{3} \mathrm{H}$ concentration versus age, we conclude that the ${ }^{3} \mathrm{H}$ concentration of the injected water is quite variable in time. The temporal variations of the ${ }^{3} \mathrm{H}$ could lead to an alternate dating technique based on the matching temporal variations. To do this, frequent monitoring of ${ }^{3} \mathrm{H}$ would be required, however, relatively inexpensive liquid scintillation beta counting of un-enriched water samples would be satisfactory. Samples should be collected daily, but then combined into larger groups.

Two other methods of age dating exist. The abundance of $85 \mathrm{Kr}$ (half-life $=10.7$ yr.) can be used for dating because the atmospheric abundance is accurately known as a function of time. Equipment for $85 \mathrm{Kr}$ measurements is currently being built at LLNL. A $85 \mathrm{Kr}$ study of injection barrier samples could be desirable for system development since the ${ }^{3} \mathrm{H}-{ }^{3} \mathrm{He}$ ages of the injection water are well defined. The other dating technique uses artificial noble gas tracers. Very small amounts of non-toxic noble gas isotopes can be added to the injection water and then detected later at monitoring wells. A suitable tracer is already at the OCWD. In general, the tracer cost is very small compared to analysis costs. The disadvantage of the tracer is that one has to wait for it to appear. However, we would recommend going ahead with a tracer experiment just on the chance we would still be interested in age determinations 2-3 years in the future. The comparison of ${ }^{3} \mathrm{H}-{ }^{3} \mathrm{He}$ ages and tracer appearance ages would be interesting and could provide additional confidence in the ${ }^{3} \mathrm{H}-{ }^{3} \mathrm{He}$ dating system.

By using ${ }^{3} \mathrm{H}$ and neon concentration measurements, we have been able to estimate mixing ratios between injected water and ambient water. We believe measurements of other dissolved noble gases besides Ne would improve the resolution in the mixing ratio measurements. The injection water is about $5^{\circ} \mathrm{C}$ warmer than the ambient water recharge temperature $\left(25^{\circ} \mathrm{C}\right.$ versus $\left.20^{\circ} \mathrm{C}\right)$. The abundances of the dissolved gases are temperature dependent with xenon showing the greatest shift with temperature $\left(4 \%\right.$ per $1^{\circ} \mathrm{C}$, for a total effect of 20\%). The advantage to using xenon measurements is that xenon concentration is well defined for both end-members instead of just one as is the case for ${ }^{3} \mathrm{H}$ and neon. A byproduct of measuring argon, krypton and xenon in addition to neon, is that the 
calculation of ${ }^{3} \mathrm{H}$-derived ${ }^{3} \mathrm{He}$ becomes more accurate and reliable because the air contribution can be better identified.

This work was performed under the auspices of the U.S.D.O.E. by LLNL under contract number W7405-Eng-48. 


\section{REFERENCES}

Ekwurzel B., Schlosser P., Smethie W.M., Plummer L.N. and others, Dating of shallow groundwater - comparison of the transient tracers $\mathrm{H}-3 / \mathrm{He}-3$, chlorofluorocarbons and $\mathrm{Kr}$ 85. Water Resources Research, 1994 JUN, v30 n6:1693-1708.

Solomon D.K., Sudicky E.A., Tritium and helium-3 isotope ratios for direct estimation of spatial variations in groundwater recharge. Water Resources Research, 1991 SEP, v27 n9:2309-2319. 


\begin{tabular}{|c|c|c|c|c|c|c|c|c|c|c|c|}
\hline Sample Name & $\begin{array}{l}\text { Well/Sample } \\
\text { Information }\end{array}$ & Aquifer & $\begin{array}{c}3 \mathrm{H} \\
(\text { atom/g) }\end{array}$ & $\begin{array}{c}4 \mathrm{He} \\
\text { (atom/g) }\end{array}$ & $\begin{array}{c}3 \mathrm{He} \\
\text { (atom/g) }\end{array}$ & $\begin{array}{c}22 \mathrm{Ne} \\
\text { (atom/g) }\end{array}$ & $\begin{array}{c}14 C \\
\text { frac modern }\end{array}$ & delta 13C & $\begin{array}{r}36 \mathrm{Cl} / \mathrm{Cl} \\
(\times 1 \mathrm{e} 15)\end{array}$ & $\begin{array}{c}\mathbf{C l} \\
\mathrm{mg} / \mathrm{L}\end{array}$ & $\begin{array}{r}\mathrm{Sr} \\
\mathrm{ug} / \mathrm{L}\end{array}$ \\
\hline Waste Water 22A (WW-1) & & & $1.76 \mathrm{E}+06$ & $1.45 E+12$ & $1.69 E+06$ & $4.64 \mathrm{E}+11$ & 0.83 & -30.4 & & & \\
\hline Waste Water 22B (WW-3) & & & & $1.19 E+12$ & $1.59 E+06$ & $4.56 E+11$ & 0.82 & -23.1 & 83.5 & 20 & 20 \\
\hline$Q-10$ & injection point & & $1.11 E+06$ & $1.59 \mathrm{E}+12$ & $1.67 E+06$ & $4.62 E+11$ & 0.37 & -16.2 & 64.8 & 22 & 37 \\
\hline DW-1 & deep well & & $<3.00 E+04$ & $2.79 E+12$ & $2.01 E+06$ & $5.83 E+11$ & 0.27 & -15.3 & & 8 & 56 \\
\hline SAKI-FV & production well & $B I, B I I, L$ & $<3.00 E+04$ & $2.02 E+12$ & $2.80 E+06$ & $7.55 E+11$ & 0.83 & -13.5 & 61.9 & 60 & \\
\hline HB-DYKE & production well & $A$ & $1.60 \mathrm{E}+07$ & $2.00 E+12$ & $4.24 E+06$ & $5.26 \mathrm{E}+11$ & 2.83 & -20.7 & 75.5 & 95 & 289 \\
\hline OCWD-M5-1 & monitoring well & $T$ & $5.19 \mathrm{E}+06$ & $1.81 E+12$ & $2.22 E+06$ & $4.85 \mathrm{E}+11$ & 1.95 & -18.6 & 85.3 & 70 & 252 \\
\hline OCWD-M5-4 & monitoring well & $\mathbf{L}$ & $1.86 \mathrm{E}+06$ & $1.77 E+12$ & $3.47 E+06$ & $5.70 E+11$ & 0.92 & -13.7 & 82.5 & 42 & 508 \\
\hline OCWD-M19-1 & monitoring well & $T$ & $5.02 E+04$ & $1.93 E+12$ & $2.73 E+06$ & $7.42 E+11$ & 0.81 & -13.1 & 69.8 & 65 & 649 \\
\hline OCWD-M19-2 & monitoring well & A & $1.50 E+06$ & $1.93 E+12$ & $2.44 E+06$ & $6.85 E+11$ & 1.32 & -14.1 & 96.2 & 75 & 425 \\
\hline OCWD-M19-3 & monitoring well & B & $1.22 E+07$ & $1.80 \mathrm{E}+12$ & $2.90 E+06$ & $5.07 E+11$ & 2.19 & -19.3 & 85.5 & 58 & 244 \\
\hline OCWD-M21-1 & monitoring well & $T$ & $1.89 E+06$ & $1.66 \mathrm{E}+12$ & $1.92 E+06$ & $5.15 \mathrm{E}+11$ & 0.98 & -16.7 & 103.0 & 33 & 62 \\
\hline OCWD-M21-2 & monitoring well & A & $6.56 E+06$ & $1.68 E+12$ & $2.05 E+06$ & $4.91 E+11$ & & & 104.0 & 75 & 203 \\
\hline OCWD-M21-3 & monitoring well & B & $2.51 E+06$ & $1.63 E+12$ & $1.95 E+06$ & $4.78 E+11$ & 1.43 & -16.8 & 94.5 & 40 & 64 \\
\hline OCWD-M21-4 & monitoring well & $L$ & $1.28 \mathrm{E}+07$ & $1.61 E+12$ & $2.17 E+06$ & $4.99 E+11$ & 1.44 & -16.2 & 91.9 & 36 & 92 \\
\hline OCWD-M11-1 & monitoring well & $\mathrm{T}$ & $7.55 E+06$ & $1.74 E+12$ & $3.32 E+06$ & $4.93 E+11$ & & & 87.3 & 90 & 419 \\
\hline OCWD-M11-4 & monitoring well & $L$ & $5.40 \mathrm{E}+07$ & $1.79 E+12$ & $8.62 E+06$ & $4.94 E+11$ & 5.55 & -19.5 & 70.0 & 80 & 408 \\
\hline OCWD-M7A-1 & monitoring well & $\mathrm{T}$ & $1.19 E+07$ & $2.05 E+12$ & $3.98 E+06$ & $5.94 \mathrm{E}+11$ & 3.03 & -18.6 & 81.5 & 80 & 328 \\
\hline OCWD-M7A-3 & monitoring well & B & $1.67 E+07$ & $2.03 E+12$ & $4.83 E+06$ & $5.94 \mathrm{E}+11$ & 3.10 & -19.5 & 87.1 & 80 & 396 \\
\hline OCWD-M26 & monitoring well & $T / L$ & $<3.00 E+04$ & & & & & & 6.2 & 1000 & \\
\hline OCWD-M31 & monitoring well & $T$ & $1.26 E+05$ & & & & 0.05 & -2.1 & 3.8 & 9000 & \\
\hline OCWD-CTG1-1 & monitoring well & A & $<3.00 E+04$ & $1.78 E+12$ & $2.42 E+06$ & $6.82 E+11$ & 0.64 & -12.1 & 42.8 & 42 & 669 \\
\hline OCWD-CTG1-2 & monitoring well & $L, O$ & $<3.00 E+04$ & $1.76 E+12$ & $2.13 E+06$ & $6.25 E+11$ & 0.59 & -10.9 & 62.1 & 15 & 395 \\
\hline OCWD-CTG1-3 & monitoring well & $\mathrm{R}, \mathrm{M}$ & $<3.00 \mathrm{E}+04$ & $2.04 E+12$ & $1.89 E+06$ & $5.31 \mathrm{E}+11$ & & & & 18 & 65 \\
\hline OCWD-CTG1-4 & monitoring well & LM & $<3.00 E+04$ & $3.13 E+12$ & $1.99 E+06$ & $5.47 \mathrm{E}+11$ & 0.28 & -18.6 & & 20 & 40 \\
\hline WM-3 & production well & $\mathrm{B}, \mathrm{L}$ ? & $<3.00 E+04$ & & & & 0.81 & -12.0 & 101.0 & 40 & 561 \\
\hline MSP-10 & monitoring well & $T$ & $6.28 E+04$ & & & & & & & & \\
\hline SA10-1 & monitoring well & $\mathrm{T}$ & $8.38 E+04$ & & & & 0.26 & -10.5 & $<8$ & 2100 & 2507 \\
\hline OCWD-M28 & monitoring well & $\mathrm{T}$ & $8.38 \mathrm{E}+04$ & & & & & & 2.2 & 4500 & \\
\hline $\begin{array}{l}\text { Seawater } \\
\text { Scale -carbonate }\end{array}$ & $\begin{array}{l}\text { Newport Pier } \\
\text { recarbonation }\end{array}$ & & $1.26 \mathrm{E}+05$ & & & & $\begin{array}{l}1.07 \\
4.02\end{array}$ & $\begin{array}{c}1.5 \\
-29.5\end{array}$ & $<.5$ & 18000 & 6807 \\
\hline
\end{tabular}




\begin{tabular}{|c|c|c|c|c|c|c|}
\hline Sample Name & $\begin{array}{r}\text { Elevation } \\
\text { water table }\end{array}$ & $\begin{array}{c}\text { Elevation } \\
\text { ground level }\end{array}$ & $\begin{array}{r}\text { Alk } \\
\text { mg/liter }\end{array}$ & $T(O C)$ & pH & $\begin{array}{r}\text { EC } \\
\text { uohm } / \mathrm{cm}\end{array}$ \\
\hline Waste Water 22A (WW-1) & & & 60 & 23.3 & 6.93 & 1078 \\
\hline Waste Water 22B (WW-3) & & & 15 & 25.1 & 6.71 & 150 \\
\hline$Q-10$ & & & 50 & & 7.46 & 243 \\
\hline$D W-1$ & & & 160 & 26.0 & 8.70 & 374 \\
\hline SAKLFV & & 32.0 & 200 & 19.8 & 7.73 & 804 \\
\hline HB-DYKE & & 53.7 & 170 & 26.0 & 7.74 & 736 \\
\hline OCWD-M5-1 & 11.1 & 22.1 & 150 & 24.9 & 7.76 & 638 \\
\hline OCWD-M5-4 & 0.0 & 22.1 & 160 & 22.7 & 7.64 & 580 \\
\hline OCWD-M19-1 & 9.3 & 21.9 & 200 & 20.2 & 7.45 & 820 \\
\hline OCWD-M19-2 & 5.9 & 21.9 & 175 & 21.3 & 7.54 & 733 \\
\hline OCWD-M19-3 & 4.4 & 21.9 & 140 & 23.0 & 7.65 & 549 \\
\hline OCWD-M21-1 & 5.8 & 22.1 & 100 & 25.4 & 7.34 & 318 \\
\hline OCWD-M21-2 & 5.7 & 22.1 & 100 & 25.0 & 7.90 & 522 \\
\hline OCWD-M21-3 & 1.7 & 22.1 & 70 & 26.4 & 7.29 & 334 \\
\hline OCWD-M21-4 & -4.8 & 22.1 & 110 & 25.0 & 7.59 & 420 \\
\hline OCWD-M11-1 & 6.8 & 18.7 & 170 & 22.3 & 7.67 & 704 \\
\hline OCWD-M11-4 & 4.7 & 18.7 & 140 & 25.1 & 7.93 & 708 \\
\hline OCWD-M7A-1 & 4.9 & 16.5 & 180 & 22.8 & 7.81 & 714 \\
\hline OCWD-M7A-3 & 4.3 & 16.5 & 150 & 22.9 & 7.81 & 662 \\
\hline OCWD-M26 & 2.9 & 8.4 & 190 & 22.5 & 7.40 & 3170 \\
\hline OCWD-M31 & 2.8 & 10.5 & 600 & 20.5 & 7.46 & 17850 \\
\hline OCWD-CTG1-1 & 31.8 & 34.0 & 200 & 21.2 & 7.75 & 755 \\
\hline OCWD-CTG1-2 & -43.8 & 34.0 & 180 & 22.9 & 7.80 & 456 \\
\hline OCWD-CTG1-3 & -29.4 & 34.0 & 145 & 22.1 & 8.91 & 370 \\
\hline OCWD-CTG1-4 & -13.2 & 34.0 & 180 & 22.9 & 9.10 & 403 \\
\hline WM-3 & & 25.0 & 230 & 18.4 & 7.60 & 739 \\
\hline MSP-10 & 21.8 & 37.0 & 350 & 19.5 & 7.12 & 1117 \\
\hline SA10-1 & 1.8 & 7.0 & 300 & 21.0 & 7.57 & 6120 \\
\hline OCWD-M28 & 2.3 & 5.8 & 450 & 20.6 & 7.39 & 14490 \\
\hline Seawater & 0.0 & 0.0 & 125 & 17.3 & 8.30 & 50800 \\
\hline
\end{tabular}




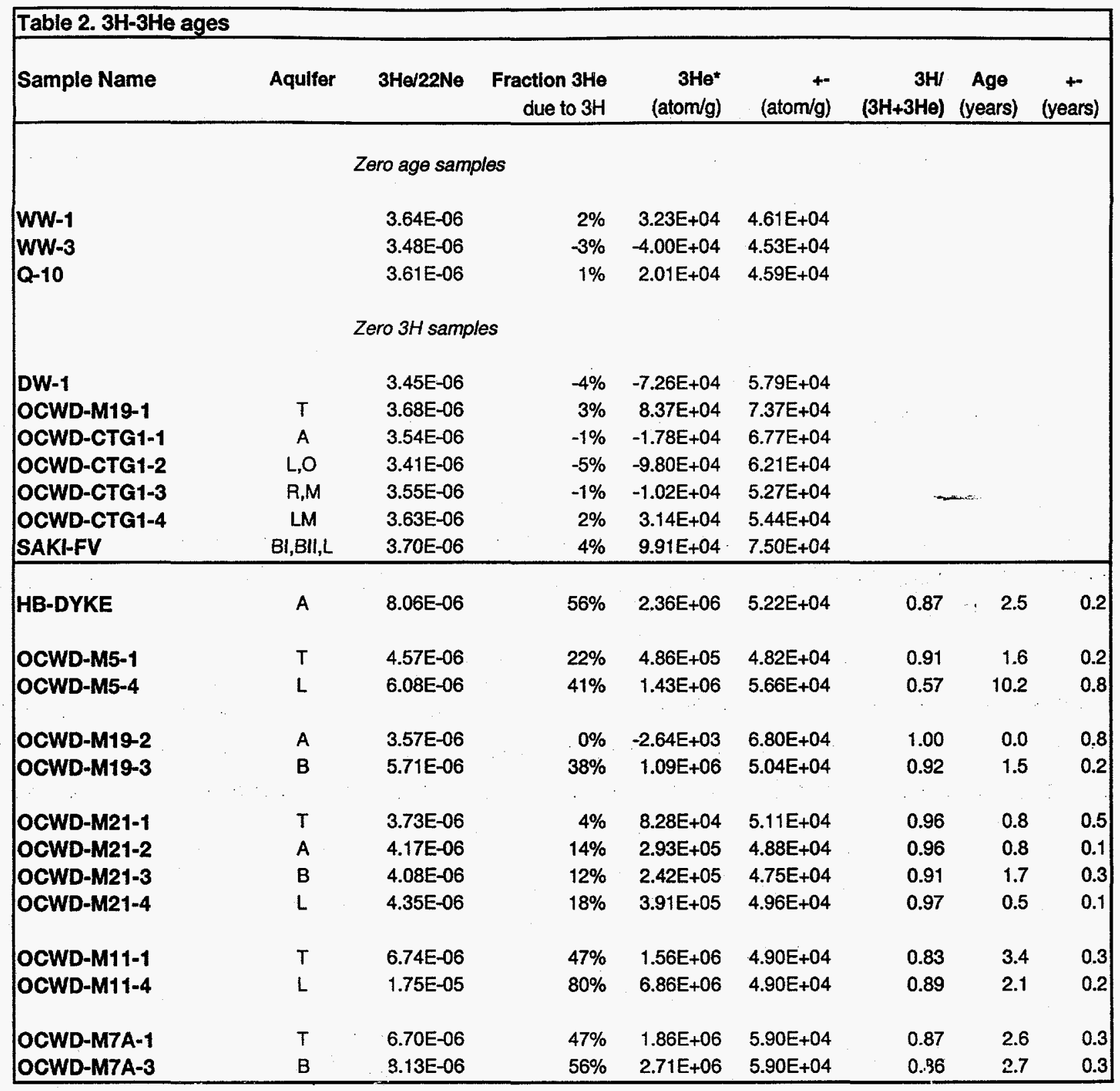




\begin{tabular}{|c|c|c|c|c|}
\hline Sample Name & $\begin{array}{r}3 \mathrm{H} \\
(\text { atom/g) } \\
\end{array}$ & $\begin{array}{r}22 \mathrm{Ne} \\
(\mathrm{atom} / \mathrm{g})\end{array}$ & delta $13 \mathrm{C}$ & $\begin{array}{r}\mathrm{T} \\
\left({ }^{\circ} \mathrm{C}\right)\end{array}$ \\
\hline \multicolumn{5}{|c|}{$\begin{array}{l}\text { Mostly ambient } \\
\text { water }\end{array}$} \\
\hline DW-1 & $<3.00 E+04$ & $5.83 E+11$ & -15.3 & \\
\hline SAKI-FV & $<3.00 E+04$ & $7.55 E+11$ & -13.5 & 19.8 \\
\hline OCWD-M19-1 & $5.02 E+04$ & $7.42 \mathrm{E}+11$ & -13.1 & 20.2 \\
\hline OCWD-CTG1-1 & $<3.00 E+04$ & $6.82 E+11$ & -12.1 & 21.2 \\
\hline OCWD-CTG1-2 & $<3.00 E+04$ & $6.25 E+11$ & -10.9 & 22.9 \\
\hline OCWD-CTG1-3 & $<3.00 E+04$ & $5.31 E+11$ & & 22.1 \\
\hline OCWD-CTG1-4 & $<3.00 E+04$ & $5.47 \mathrm{E}+11$ & -18.6 & 22.9 \\
\hline WM-3 & $<3.00 E+04$ & & -12.0 & 18.4 \\
\hline average & $<3.00 E+04$ & $6.38 E+11$ & -13.6 & 21.4 \\
\hline & & & & \\
\hline \multicolumn{5}{|c|}{ Both ambient and injection water } \\
\hline OCWD-M5-4 & $1.86 E+06$ & $5.70 E+11$ & -13.7 & 22.7 \\
\hline OCWD-M19-2 & $1.50 \mathrm{E}+06$ & $6.85 E+11$ & -14.1 & 21.3 \\
\hline OCWD-M7A-1 & $1.19 E+07$ & $5.94 E+11$ & -18.6 & 22.8 \\
\hline OCWD-M7A-3 & $1.67 \varepsilon+07$ & $5.94 E+11$ & -19.5 & 22.9 \\
\hline average & $7.99 E+06$ & $6.11 E+11$ & -16.5 & 22.4 \\
\hline std dev & $94 \%$ & $8 \%$ & $18 \%$ & $3 \%$ \\
\hline \multicolumn{5}{|c|}{ Mostly injection water } \\
\hline$w W-1$ & $2.09 E+06$ & $4.64 E+11$ & -30.4 & 23.3 \\
\hline$W W-3$ & $2.09 E+06$ & $4.56 E+11$ & -23.1 & 25.1 \\
\hline$Q-10$ & $1.11 E+06$ & $4.62 E+11$ & -16.2 & \\
\hline HB-DYKE & $1.60 E+07$ & $5.26 \mathrm{E}+11$ & -20.7 & 26.0 \\
\hline OCWD-M5-1 & $5.19 E+06$ & $4.85 E+11$ & -18.6 & 24.9 \\
\hline OCWD-M19-3 & $1.22 E+07$ & $5.07 E+11$ & -19.3 & 23.0 \\
\hline OCWD-M21-1 & $1.89 E+06$ & $5.15 E+11$ & -16.7 & 25.4 \\
\hline OCWD-M21-2 & $6.56 E+06$ & $4.91 E+11$ & & 25.0 \\
\hline OCWD-M21-3 & $2.51 E+06$ & $4.78 E+11$ & -16.8 & 26.4 \\
\hline OCWD-M21-4 & $1.28 \mathrm{E}+07$ & $4.99 E+11$ & -16.2 & 25.0 \\
\hline OCWD-M11-1 & $7.55 E+06$ & $4.93 E+11$ & & 22.3 \\
\hline OCWD-M11-4 & $5.40 E+07$ & $4.94 E+11$ & -19.5 & 25.1 \\
\hline average & $1.03 E+07$ & $4.89 E+11$ & -19.7 & 24.7 \\
\hline std dev & $142 \%$ & $4 \%$ & $22 \%$ & $5 \%$ \\
\hline $\begin{array}{l}\text { water at } 2^{\circ} \mathrm{C} \\
\text { average groundwater }\end{array}$ & & $\begin{array}{l}4.61 E+11 \\
6.87 E+11\end{array}$ & & \\
\hline
\end{tabular}




\section{List of Figures}

1. Piper diagram of groundwaters sampled for isotopic analysis. The different groundwater types are indicated. Some TDS values (circles) are too large for this figure and are not shown.

2. Map of the Talbert Gap study area.

3. Graph of ${ }^{3} \mathrm{He} / 22 \mathrm{Ne}$ showing excess ${ }^{3} \mathrm{He}$ in some samples. The samples which are zero age or have zero ${ }^{3} \mathrm{H}$ give a value nearly identical to that for water in equilibrium with air.

4. Chlorine isotopes show the effects of evaporation which concentrates $\mathrm{Cl}$ but does not change the ratio of $36 \mathrm{Cl} / \mathrm{Cl}$ and the addition of seawater which is rich in stable $\mathrm{Cl}$ but not radioactive ${ }^{36} \mathrm{Cl}\left(\mathrm{t}_{1 / 2}=3 \times 10^{5} \mathrm{yr}\right)$. Most notable is the lack large amounts of $36 \mathrm{Cl}$ in samples high in ${ }^{3} \mathrm{H}$.

5. Strontium concentration increases as a function of time (as measured by ${ }^{3} \mathrm{H}-{ }^{3} \mathrm{He}$ ages) in the aquifer unit. The increase is not due to mixing (as shown by the Ne data) and must be the result of chemical interaction between aquifer materials and the blended injection water. 
Figure 1. Piper diagram of groundwaters sampled for isotopic analysis.

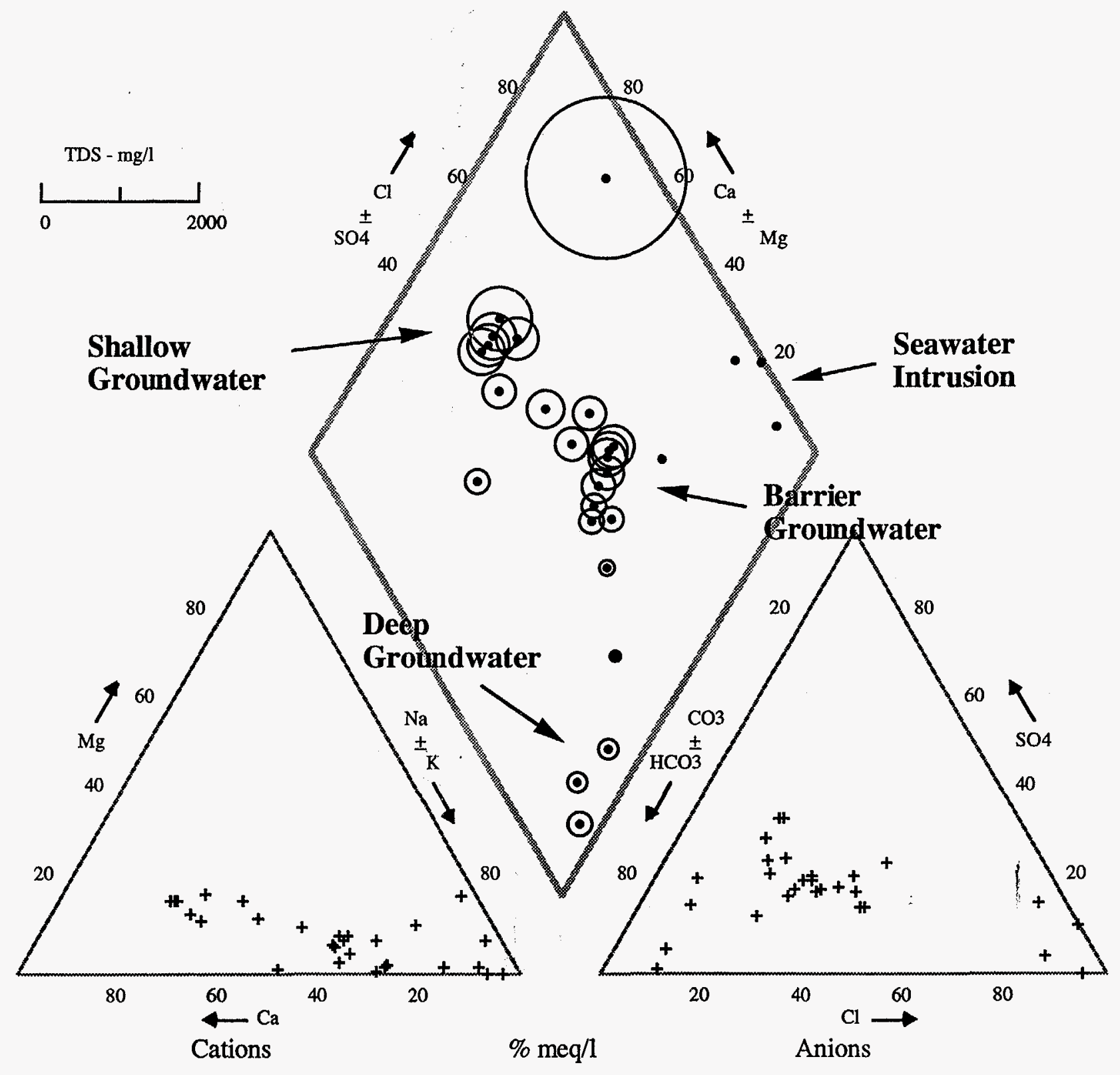


Figure 2. Talbert Gap (Orange County, CA)

STUDY AREA AND WELL LOCATION MAP

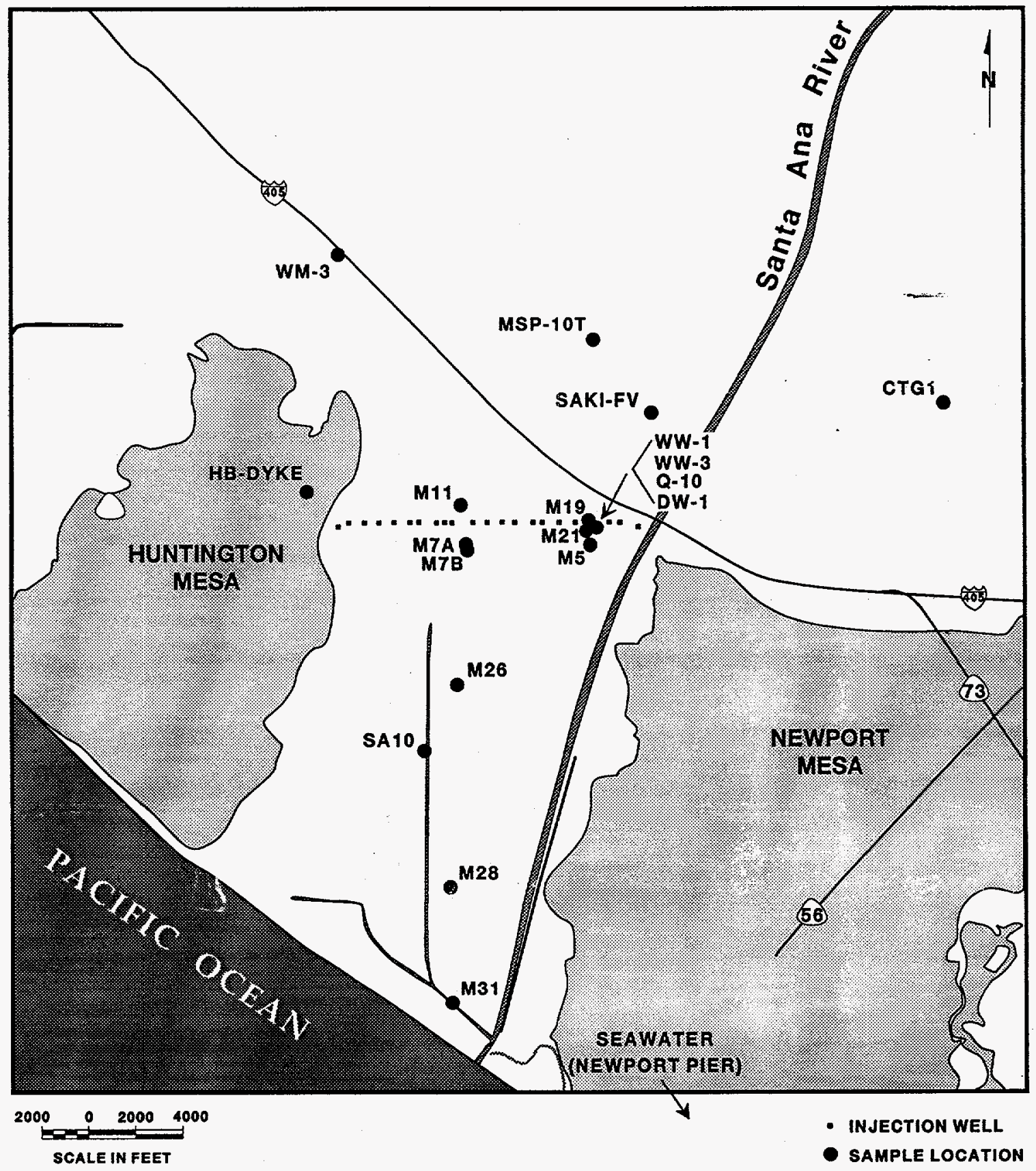




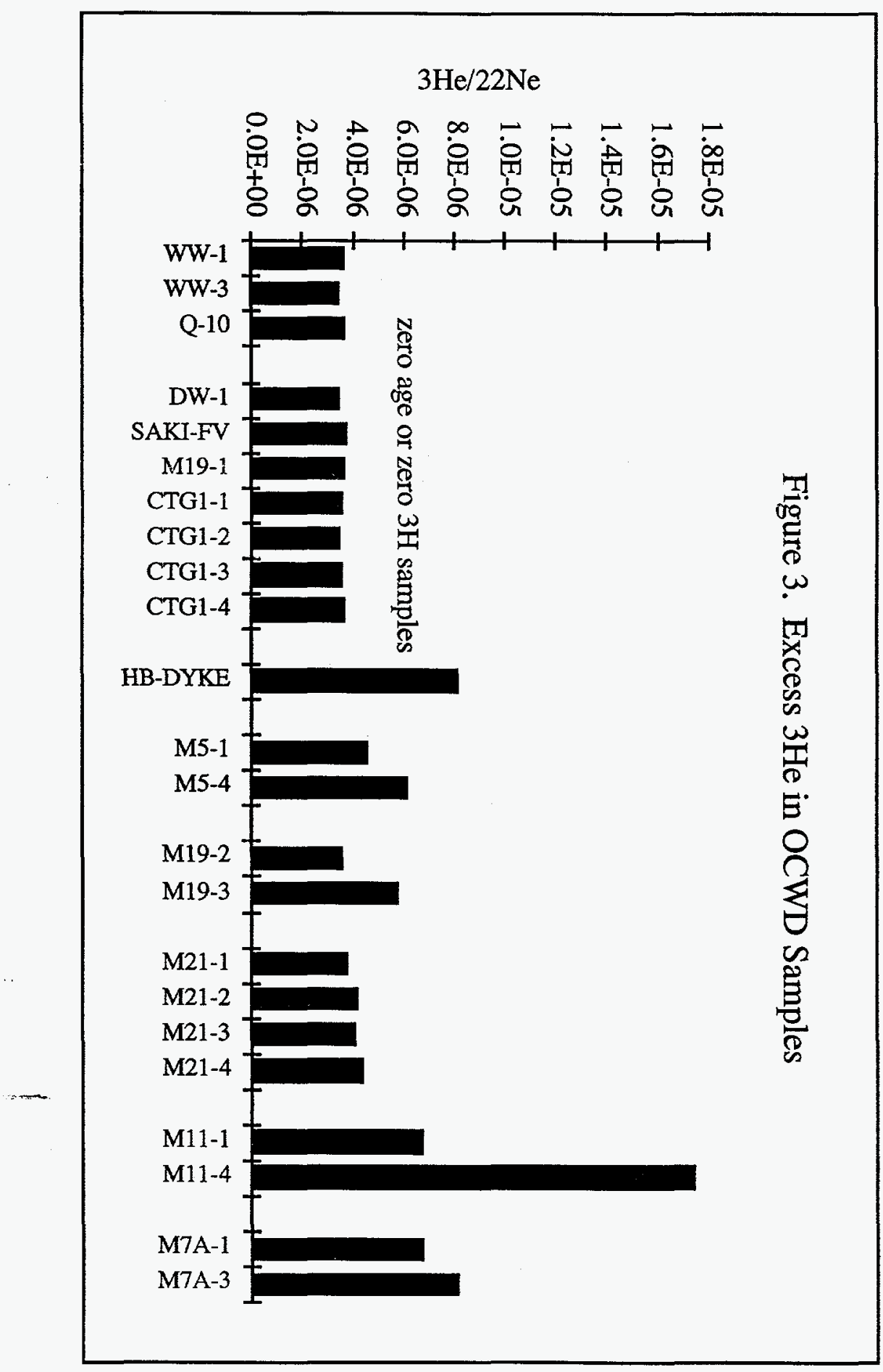




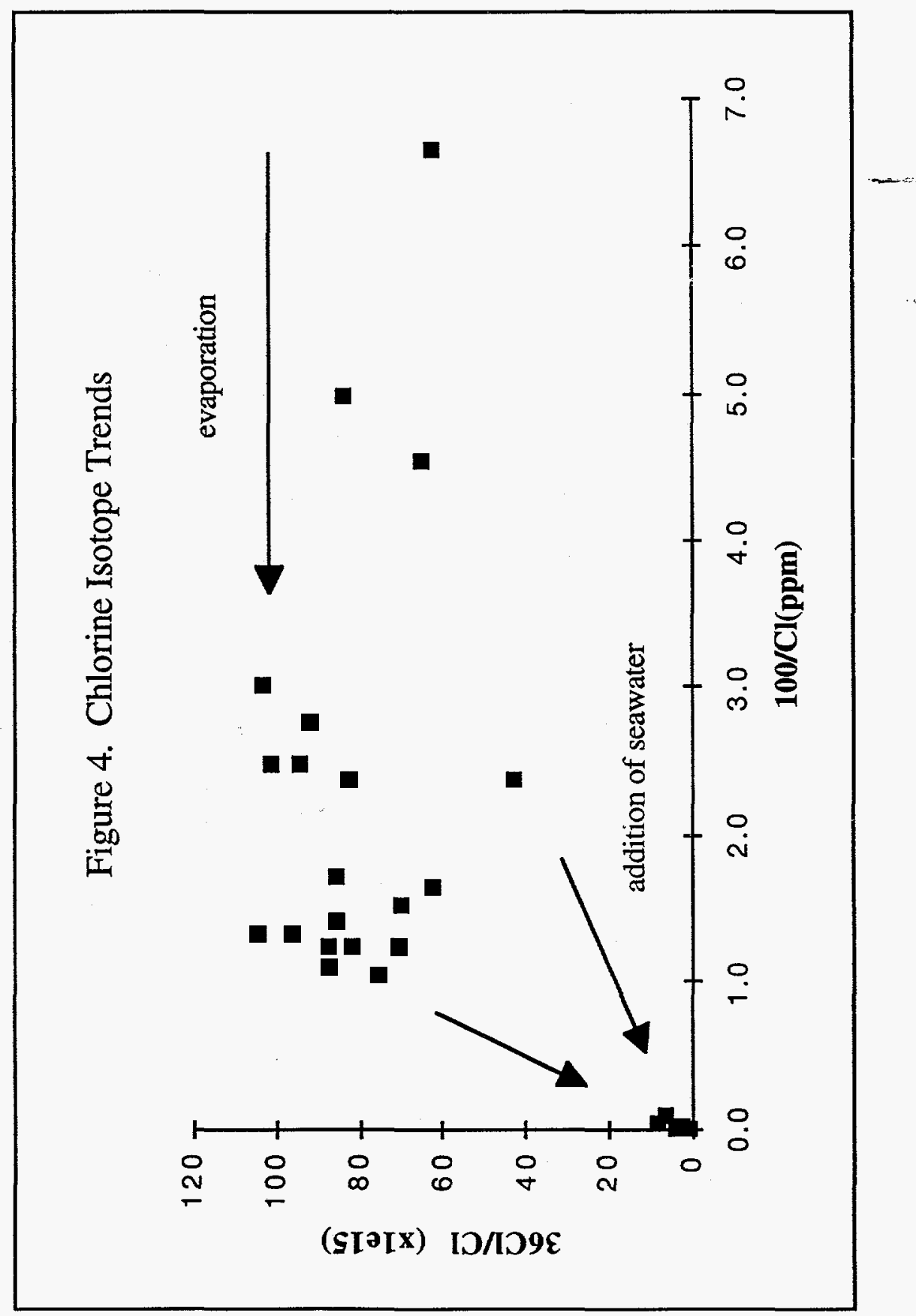




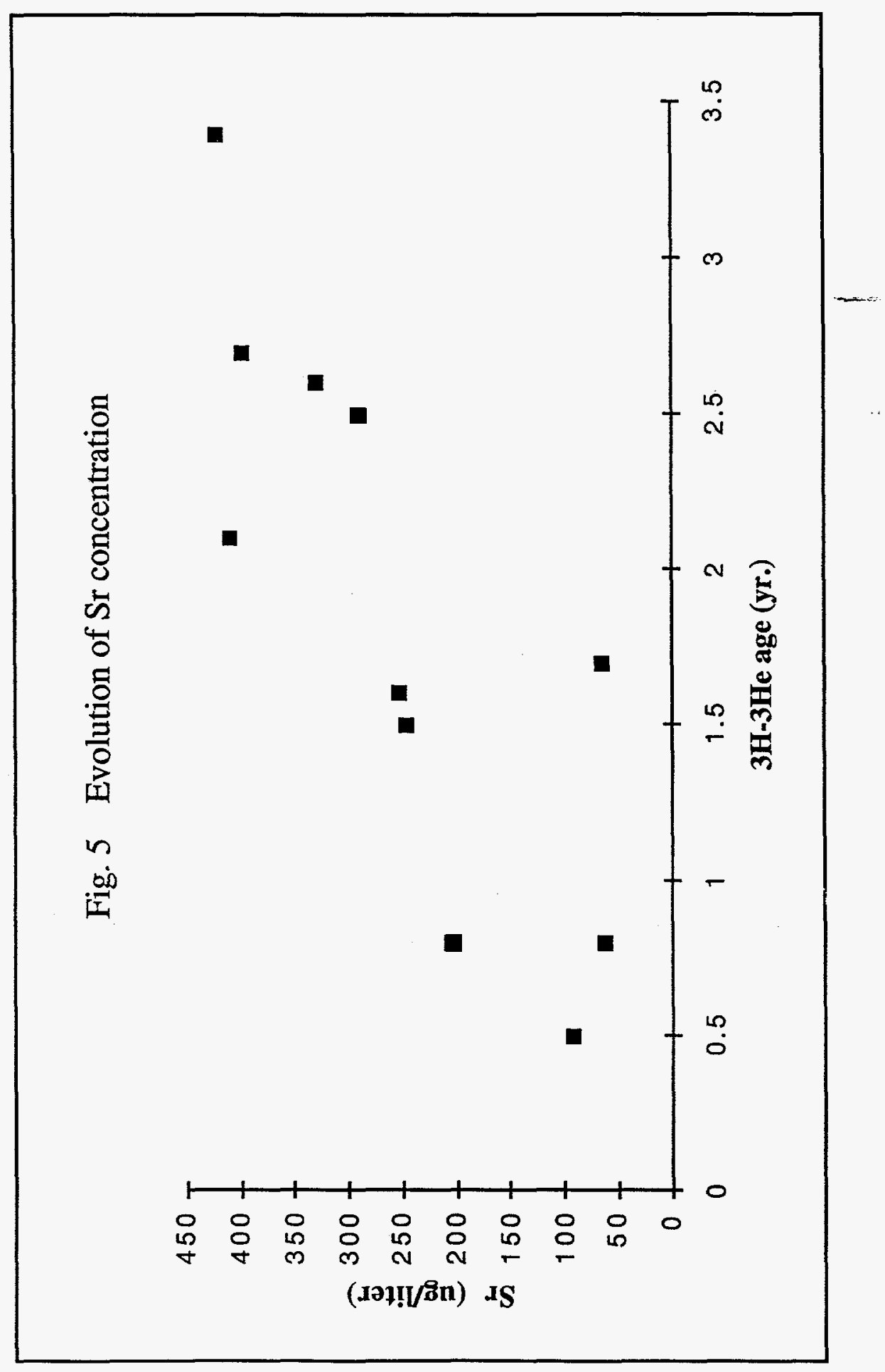

